\title{
POSSIBILITY OF USING BIOCHEMICAL AND HEMATOLOGICAL PARAMETERS IN EVALUATING ADNEXAL MASSES
}

\author{
Aleksandra Petrić1,2, Radomir Živadinović1,2, Dejan Mitić1,2, Predrag Vukomanović1,2, \\ Jelena Milošević1,2, Aleksandar Živadinović ${ }^{2}$
}

\begin{abstract}
Current diagnostic approach to adnexal masses (medical history, clinical examination, transvaginal sonography, tumour markers) does not provide an accurate prediction for potential malignancy. There is a possibility of using hematological and biochemical parameters (platelets count, neutrophil/lymphocyte ratio, platelet/lymphocyte ratio, platelet distribution width, level of C-reactive protein) in predicting ovarian malignancy. A retrospective study was conducted. Analysis of aforementioned parameters was performed in patients with histopathologically verified benign/malignant ovarian tumours. CRP levels, total count of granulocytes, and total count of platelets were statistically significantly higher in patients with malignant changes $(p<$ $0.001, p=0,001$, or $p=0.023$ ). Total lymphocytes count was statistically significantly lower in patients with malignant changes $(p<0.001)$. Platelet count was statistically significantly higher in patients with stage III $(p=0.011)$. PI/LY ratio was statistically significantly higher in patients with stage III $(p=0.043)$. CRP was statistically significantly higher in stage III $(p<0.001)$. Lymphocyte count was statistically significantly lower in stage III $(p<0.001)$, and granulocyte count was statistically significantly higher in stage III $(p=0.001)$. Platelet count was statistically significantly higher in stage III $(p=0.001)$. MPV was statistically significantly lower in stage III $(p=0.031)$. Pl/Ly ratio was statistically significantly higher in patients with stage III $(p=0.044)$. Analyzed biochemical and hematological parameters are of limited utility in differentiating benign from malignant ovarian masses. Elevated levels of C-reactive protein, neutrophils and platelets suggest potentially malignant ovarian masses. Analyzed biochemical parameter (high levels of C-reactive protein, reduced lymphocyte count, increased granulocyte count, increased platelet count, increased PLR, as well as lower MPV values) may suggest advanced malignancy.
\end{abstract}

Acta Medica Medianae 2021;60(4):23-29.

Key words: ovarian tumours, biochemical, hematological parameter

${ }^{1}$ University of Niš, Faculty of Medicine, Niš, Serbia

${ }^{2}$ University Clinical Center Niš, Clinic for Gynecology and

Obstetrics, Niš, Serbia

Contact: Aleksandra Petrić

3/17 Lole Ribara Str., 18000 Niš, Serbia

E-mail: sanja.petric@hotmail.com

\section{Introduction}

Adnexal masses represent different changes of gynaecological (functional cysts, inflammatory changes, benign and malignant neoplasma) and nongynaeacological origin. It is not diagnosed easily and diagnostic errors and problems are possible (14). Evaluation of adnexal masses involves an accurate anamnesis, careful clinical examination, transvaginal sonography, and determination of tumour markers. Ultrasound diagnostics is non-invasive, cheap and available for adnexal masses evaluation. Transvaginal sonography is the preferred technique (no need for special equipment, area of interest is close to the probe). Ultrasound diagnostics identifies adnexal masses. Masses that are bilateral, large, complex, irregular, and accompanied by ascites are considered suspicious (5). By using ultrasound as a diagnostic tool, patients can be grouped into those in whom surveillance using serial ultrasonography can be applied, and those who require surgery (6). The Gynecologic Imaging Reporting and Data System (GI-RADS) is a reporting system that was created for reporting the findings in adnexal masses based on transvaginal ultrasonography (7). Still, there is a possibility that GI-RADS classification gives a great number of false-positive results, so it is recommended to additionally use tumour markers. Additional measurements to GI-RADS system do not alter clinical approach (6-9).

The success of surgical treatment depends on appropriate preoperative plan. There is a need to define steps in treating indeterminate adnexal changes (10). Monitoring the morphology of tu- 
mours, the presence of ascites, and Doppler parameters facilitate approaches in making preoperative plans and the choice of medical center for patients to be treated. Patients with diagnosed adnexal masses indicative of malignancy should be referred to a gyneacological oncologist for optimal patient treatment (11). Surgeries performed by a welltrained surgeon, in a well-equipped center, provide optimal surgical treatment (12-15).

Current diagnostic approach to adnexal masses (history taking, clinical examination, transvaginal sonography, tumour markers) does not provide accurate prediction of potential malignancy, thus potentially affecting the choice and time of treatment, the choice of medical center, specialist doctor and surgical approach (laparotomy/laparoscopy). There is a need to define additional parameters for a more accurate preoperative prediction of potential malignancy. There is a possibility to utilize hematological parameters (platelets count, neutrophil/lymphocyte ratio, platelet/lymphocyte ratio, platelet distribution width) that have been used in routine preoperative diagnostics and preoperative preparation. Preoperative determination of these parameters is cheap, available, repeatable, and potentially useful in evaluating adnexal masses (16-20).

\section{Methods of the study}

The study is a retrospective one. Patients operated at out Clinic for diagnosed adnexal masses were analyzed. The study enrolled 100 surgically treated patients. They were all operated for ovarian tumours, and all of them were operated at our Clinic according to current oncologic principles (full staging). Standard hematological and biochemical parameters were controlled preoperatively. After the surgery, according to histopathological reports on removed adnexal masses, we formed a group of patients with benign ovarian tumours and a group of patients with malignant ovarian tumours. Patients with detected inflammatory changes (tubo-ovarian abscesses), metastatic ovarian changes, as well as patients with incomplete staging were excluded from the study.

Patients' age, histopathological type of tumour, and stage of the disease were analyzed in patients with malignant ovarian disease. Preoperative hematological parameters, total count of erythrocytes $/ \mathrm{ml}$, total count of leukocytes $/ \mathrm{ml}$, total count of neutrophils $/ \mathrm{ml}$, lymphocyte count $/ \mathrm{ml}$, monocyte count $/ \mathrm{ml}$, platelet count $/ \mathrm{ml}$, neutrophils/platelets count ratio, neutrophils/lymphocyte count ratio, platelet distribution width, platelet volume, and the level of C-reactive protein were analyzed in both groups.

Biochemical and hematological parameters were compared in patients with adnexal masses: a group with histopathologically verified benign ovarian tumours, and a group with verified malignant ovarian neoplasm.

The analyzed parameters were compared in relation to histopathological type of malignant ova- rian tumour. We also observed the possibility of statistical difference in monitored biochemical parameters between the groups with early and advanced ovarian cancer, as well as between benign ovarian tumours and values of monitored parameters in patients with advanced ovary cancer (stage III).

\section{Statistical data processing}

The data are presented in the form of arithmetic mean \pm standard deviation. If data distribution was normal, t-test and ANOVA were used. If not, Mann-Whitney test and Kruskal-Wallis test were used. Hypothesis was tested with significance threshold of $p<0.05$ : Statistical data analysis was performed by software package SPSS 16.0.

\section{Results}

The study enrolled 100 patients, mean age $51.40 \pm 15.92$ years (Min 19, Max 83 years). Patients with malignant adnexal changes were statistically significantly older in comparison to patients with benign changes $(p=0.037)$. CRP values, total count of granulocytes and total count of platelets were statistically significantly higher in patients with malignant changes $(p<0.001, p=0.001$, or $p=$ 0.023 ). Total count of lymphocytes was statistically significantly lower in patients with malignant changes $(p<0.001)$. Other analyzed parameters showed no statistically significant difference in total count of erythrocytes and monocytes. Also, there was no statistically significant difference in the parameters related to platelet characteristics (MPV, PCT, PDW), neither regarding neutrophil/lymphocyte count ratio nor platelet/lymphocyte count (Table 1 ).

In the group with malignant tumours, 25 patients $(50.0 \%)$ had serous carcinoma, 14 patients $(28.0 \%)$ mucinous carcinoma, and 11 patients $(22.0 \%)$ had other types of carcinoma. It has been noted that there was no statistically significant difference in relation to histopahological type of cancer (Table 2).

There were 20 patients $(40.0 \%)$ in the group with malignant disease stage I, 7 patients $(14.0 \%)$ in the stage II group and 23 patients (46.0\%) in the stage III group. Platelet count was statistically significantly higher in patients with stage III ( $p=$ $0.011)$. PI/LY ratio was statistically significantly higher in patients with stage III $(p=0.043)$ (Table 3).

Patients with stage III disease were statistically significantly older $(p=0.003)$. CRP was statistically significantly higher in stage III $(p<0.001)$. Lymphocyte count was statistically significantly lower in stage III $(p<0.001)$, and granulocyte count was statistically significantly higher in stage III $(p=0.001)$. Platelet count was statistically significantly higher in stage III $(p=0.001)$. MPV was statistically significantly lower in stage III $(p=0.031)$. $\mathrm{PI} / \mathrm{Ly}$ ratio was statistically significantly higher in patients with stage III disease $(p=0.044)$ (Table 4). 
Table 1. Biochemical and hemoatological parameters in analyzed population in comparison to the type of change (benign/malignant)

\begin{tabular}{||c||c|c|c|c|}
\cline { 2 - 5 } \multicolumn{1}{c|}{} & Total & Malignant & Benign & $p$ \\
\hline \hline Age & $51.40 \pm 15.92$ & $54.44 \pm 15.47$ & $48.36 \pm 15,94$ & $0.037^{1}$ \\
\hline CRP & $17.84 \pm 35.05$ & $30.46 \pm 46.09$ & $5.22 \pm 5.78$ & $<0.001^{2}$ \\
\hline ER & $4.37 \pm 0.50$ & $4.35 \pm 0.57$ & $4.38 \pm 0.41$ & $0.737^{1}$ \\
\hline LE & $8.74 \pm 3.49$ & $8.46 \pm 3.23$ & $9.01 \pm 3.75$ & $0.699^{2}$ \\
\hline LY & $4.42 \pm 3.16$ & $3.07 \pm 2.43$ & $5.77 \pm 3.26$ & $<0.001^{2}$ \\
\hline GR & $3.75 \pm 3.04$ & $4.65 \pm 3.26$ & $2.84 \pm 2.50$ & $0.001^{2}$ \\
\hline MO & $3.51 \pm 29.06$ & $6.51 \pm 41.07$ & $0.50 \pm 0.30$ & $0.252^{2}$ \\
\hline TR & $287.29 \pm 112.30$ & $316.26 \pm 138.75$ & $258.32 \pm 67.21$ & $0.023^{2}$ \\
\hline MPV & $10.20 \pm 12.11$ & $9.78 \pm 11.56$ & $10.62 \pm 12.74$ & $0.062^{2}$ \\
\hline PCT & $0.26 \pm 1.18$ & $0.38 \pm 1.67$ & $0.15 \pm 0.14$ & $0.887^{2}$ \\
\hline PDW & $16.33 \pm 5.17$ & $16.37 \pm 5.87$ & $16.30 \pm 4.46$ & $0.468^{2}$ \\
\hline Ne/Ly & $3.54 \pm 3.12$ & $4.11 \pm 4.05$ & $2.96 \pm 1.59$ & $0.339^{2}$ \\
\hline Tr/ly & $155.05 \pm 125.69$ & $178.30 \pm 157.95$ & $131.80 \pm 76.58$ & $0.394^{2}$ \\
\hline \hline
\end{tabular}

1- t test, 2- Mann-Whitney test

Table 2. Biochemical parameters in relation to histopathological type of malignant tumours

\begin{tabular}{||c||c|c|c|c||}
\cline { 2 - 5 } \multicolumn{1}{c||}{} & Serous & Mucinous & Other & $\mathrm{p}^{1}$ \\
\hline \hline Age & $58.36 \pm 14.61$ & $52.57 \pm 14.72$ & $47.91 \pm 16.99$ & 0.138 \\
\hline CRP & $30.32 \pm 40.34$ & $41.81 \pm 65.10$ & $16.33 \pm 24.33$ & $0.449^{2}$ \\
\hline ER & $4.33 \pm 0.60$ & $4.27 \pm 0.53$ & $4.50 \pm 0.57$ & 0.588 \\
\hline LE & $8.44 \pm 3.35$ & $9.18 \pm 2.43$ & $7.61 \pm 3.89$ & $0.238^{2}$ \\
\hline LY & $2.89 \pm 2.25$ & $3.31 \pm 2.22$ & $3.17 \pm 3.20$ & $0.802^{2}$ \\
\hline GR & $4.98 \pm 3.17$ & $5.03 \pm 2.96$ & $3.43 \pm 3.86$ & $0.081^{2}$ \\
\hline MO & $0.55 \pm 0.29$ & $1.19 \pm 2.43$ & $26.84 \pm 87.61$ & $0.551^{2}$ \\
\hline TR & $357.36 \pm 163.05$ & $289.42 \pm 84.72$ & $256.99 \pm 109.98$ & $0.235^{2}$ \\
\hline MPV & $8.30 \pm 1.29$ & $7.99 \pm 1.34$ & $15.40 \pm 24.58$ & $0.186^{2}$ \\
\hline PCT & $0.16 \pm 0.17$ & $0.14 \pm 0.22$ & $1.20 \pm 3.55$ & $0.715^{2}$ \\
\hline PDW & $16.15 \pm 4.53$ & $14.23 \pm 6.31$ & $19.89 \pm 7.00$ & $0.215^{2}$ \\
\hline Ne/Ly & $3.81 \pm 3.98$ & $4.06 \pm 2.52$ & $4.88 \pm 5.76$ & $0.697^{2}$ \\
\hline Pl/ly & $221.08 \pm 193.50$ & $131.57 \pm 114.34$ & $140.54 \pm 78.70$ & $0.189^{2}$ \\
\hline
\end{tabular}

1- ANOVA, 2- Kruskal-Wallis test

Table 3. Biochemical parameters in relation to the stage of the disease

\begin{tabular}{||c||c|c|c||}
\cline { 2 - 4 } \multicolumn{1}{c||}{} & Stage I+II & Stage III & $\mathrm{p}^{1}$ \\
\hline \hline Age & $5048 \pm 16.60$ & $59.09 \pm 12.87$ & 0.071 \\
\hline CRP & $28.08 \pm 50.91$ & $33.25 \pm 40.66$ & 0.102 \\
\hline ER & $4.34 \pm 0.52$ & $4.37 \pm 0.64$ & 0.953 \\
\hline LE & $7.77 \pm 2.92$ & $9.28 \pm 3.45$ & 0.104 \\
\hline LY & $2.93 \pm 2.24$ & $3.24 \pm 2.69$ & 0.97 \\
\hline GR & $4.13 \pm 3.11$ & $5.27 \pm 3.42$ & 0.185 \\
\hline MO & $11.54 \pm 55.88$ & $0.62 \pm 0.31$ & 0.066 \\
\hline TR & $266.59 \pm 97.50$ & $374.56 \pm 158.30$ & 0.011 \\
\hline MPV & $11.12 \pm 15.70$ & $8.20 \pm 1.40$ & 0.325 \\
\hline PCT & $0.56 \pm 2.27$ & $0.18 \pm 0.17$ & 0.115 \\
\hline PDW & $16.20 \pm 7.10$ & $16.57 \pm 4.12$ & 0.942 \\
\hline Ne/Ly & $4.23 \pm 4.06$ & $3.97 \pm 4.13$ & 0.899 \\
\hline PI/Ly & $141.59 \pm 129.62$ & $221.39 \pm 179.22$ & 0.043 \\
\hline
\end{tabular}

1-Mann-Whitney test 
Table 4. Comparison of biochemical parameters between patients with ovarian carcinoma stage III and patients with benign ovarian tumours

\begin{tabular}{|c||c|c|c||}
\cline { 2 - 4 } \multicolumn{1}{c||}{} & $\begin{array}{c}\text { Ovarian carcinoma } \\
\text { stage III }\end{array}$ & Benign tumours & $P$ \\
\hline Age & $59.09 \pm 12.87$ & $48.36 \pm 15.94$ & $0.003^{1}$ \\
\hline CRP & $33.25 \pm 40.66$ & $5.22 \pm 5.78$ & $<0.001^{2}$ \\
\hline ER & $4.37 \pm 0.64$ & $4.38 \pm 0.41$ & $0.906^{1}$ \\
\hline LE & $9.28 \pm 3.45$ & $9.01 \pm 3.75$ & $0.510^{2}$ \\
\hline LY & $3.24 \pm 2.69$ & $5.77 \pm 3.26$ & $<0.001^{2}$ \\
\hline GR & $5.26 \pm 3.42$ & $2.84 \pm 2.50$ & $0.001^{2}$ \\
\hline MO & $0.62 \pm 0.30$ & $0.50 \pm 0.30$ & $0.064^{2}$ \\
\hline TR & $374.56 \pm 158.30$ & $258.32 \pm 67.21$ & $0.001^{2}$ \\
\hline MPV & $8.20 \pm 1.40$ & $10.62 \pm 12.74$ & $0.031^{2}$ \\
\hline PCT & $0.18 \pm 0.17$ & $0.15 \pm 0.14$ & $0.242^{2}$ \\
\hline PDW & $16.57 \pm 4.12$ & $16.30 \pm 4.46$ & $0.582^{2}$ \\
\hline Ne/Ly & $3.97 \pm 4.13$ & $2.96 \pm 1.59$ & $0.288^{2}$ \\
\hline Tr/ly & $221.39 \pm 179.22$ & $131.80 \pm 76.58$ & $0.044^{2}$ \\
\hline \hline
\end{tabular}

1- t test, 2- Mann-Whitney test

\section{Discussion}

Inflammation and inflammatory response play a pivotal role in the development and progression of malignant diseases. Biochemical and hematological inflammatory markers may be incorporated into prognostic score for various carcinoma types. Patients with malignant ovarian tumours had statistically significantly higher values of C-reactive protein and higher levels of total granulocytes, as observed in our study. High levels of C-reactive protein and leukocytosis are markers of systemic inflammatory response. Many studies suggest that high neutrophil-to-leukocyte ratio (N/LR) is associated with poor survival rate in patients with malignant diseases (20). It seems that an increase of NLR is greater in patients with metastatic disease and longer inflammatory response (21). We have not observed statistically significant difference in NLR between the group with malignant and the group with benign ovarian changes. We also have not registered statistically significant difference in this parameter by comparing groups of patients with an early and advance disease stage III (21). Our study showed that patients with advanced disease had significantly higher count of granulocytes in comparison to those with benign ovarian changes. Neutrophils have a role in immune response, they inhibit the immune system by suppressing cytolytic activity of Iymphocytes (22). The presence of tumour-infiltrating lymphocytes is suggestive of better response to treatment (23). Patients in our study have statistically significantly lower total lymphocyte count. A change in neutrophil to lymphocyte ratio may be more useful in tailoring therapy for patients with advanced malignant disease, rather than being an early disease marker (21). There is evidence that neutrophil-to-leukocyte ratio is an available marker of systemic inflammation, but, it has also been reported that this ratio may be useful in predicting operable disease and in forming pretreatment and preoperative strategy (24).

Research has shown that inflammation plays a key role in cancer pathogenesis. It affects tumour microenvironment, cell proliferation signaling, factors that impact programmed cell death, proangiogenesis, capability for invasion and metastasis (25). Inflammation may be evident in some cases at early stages of neoplastic progression. It is believed that inflammatory cells can release agents that may accelerate genetic changes (25).

Besides aforementioned parameters, a complete blood count also includes platelet count and platelet indices. We followed platelet count (Tr, Plt), mean platelet volume (MPV), plateletcrit (Pct) and platelet distribution width (PDW). PDW - Platelet distribution width represents a variation of platelet size distribution index (distribution curves for platelet distribution width). This platelet index is calculated from the distribution curve of the platelet volume and represents the width of the curve. Platelet distribution width (PDW) is a regular parameter in blood routine examination which reflects variation of platelet size distribution with a range from $8.3 \%$ to $56.6 \%$ (26). Morphological changes of platelets are always present when they are activated during inflammatory response. Plateletcrit (Pct) is a platelet index representing platelet volume as a percentage, or the relation between a total volume of full blood sample and the total number of platelets. Diagnostic value of this index remains to be seen (26).

Our study showed that patients with malignant ovarian tumours had statistically significantly higher platelet levels, but there was no statistically significant difference in PLR in comparison to the patients with benign changes. Some authors report that, despite limited sensitivity and specificity, PLR and NLR may be used as predictive factors for survival $(19,27)$. We have not found a statistically significant difference in platelet count and platelet parameters in benign/malignant changes (20). 
Expressed inflammation, thrombocytosis, and platelet hyperreactivity are often associated with malignancies. In our patients with advanced stages, thrombocytosis, higher PLR and low MPV were registered. Some of these parameters are associated with advanced stages of the disease, inoperability and poor outcome, so these parameters are more useful in predicting advanced stage disease than as early disease markers (18).

\section{Conclusion}

The analyzed biochemical parameters are of limited value in differentiating benign from malignant ovarian masses. Elevated levels of C-reactive protein, neutrophils and platelets are indicative of potentially malignant ovarian mass.

The analyzed biochemical parameters (high levels of C-reactive protein, low lymphocyte count, higher granulocyte count, higher platelet count, elevated PLR and lower levels of MPV) may be suggestive of advanced malignant disease, thus potentially changing therapeutic approach. 


\section{References}

1. Thakur M, Thakur A, Mahajan K, Rathore S, Jindal A, Gupta G. An Interesting Case of Misdiagnosed Adnexal Mass. ASMS 2018;2(1):30-32.

2. Kokanalı MK, Cavkaytrar S, Bozkurt S, Türker $M$, Aydın F, Doğanay M. Misdiagnosis of a Right Adnexal Mass: A Peculiar Case of Benign Appendiceal Mucocele. J Gynecol Surg 2016;32(1):51-3. [CrossRef]

3. Sah SK, Shi X, Silin D, Li X, Shah S, Shresta K et al. CT findings and analysis for misdiagnosis of female pelvic tuberculosis. Radiol Infect Dis 2017;4(1):19-25. [CrossRef]

4. Petric A, Tubic Pavlovic A, Djordjevic I, Vucetic D, Zivadinovic R, Krtinic et al. Echinococcosis of Iliopsoas Muscle and Anaphylaxis as the Cause of Urgent Laparotomy. West Indian Med J 2014;1(3):111-3.

5. Biggs WS, Marks ST. Diagnosis and Management of Adnexal Masses. Am Fam Physician 2016;93(8):67681. [PubMed]

6. Behnamfar F, Adibi A, Khadra H, Moradi M. Diagnostic accuracy of gynecology imaging reporting and data system in evaluation of adnexal lesions. J Res Med Sci 2019;24:57. [CrossRef] [PubMed]

7. Amor $F$, Alcázar JL, Vaccaro $H$, León $M$, Iturra $A$. GIRADS reporting system for ultrasound evaluation of adnexal masses in clinical practice: a prospective multicenter study. Ultrasound Obstet Gynecol 2011; 38(4):450-5. [CrossRef] [PubMed]

8. Zheng $H$, Tie $Y$, Wang $X, Y$ Yang $Y$, Wei $X$, Zhao $X$. Assessment of the diagnostic value of using serum CA125 and GI-RADS system in the evaluation of adnexal masses. Medicine (Baltimore) 2019;98(7): 14577. [CrossRef] [PubMed]

9. Migda M, Bartosz M, Migda MS, Kierszk M, Katarzyna G, Maleńczyk M. Diagnostic value of the gynecology imaging reporting and data system (GI-RADS) with the ovarian malignancy marker CA-125 in preoperative adnexal tumor assessment. J Ovarian Res 2018;11(1):92. [CrossRef] [PubMed]

10. Glanc $P$, Benacerraf $B$, Bourne $T$, Brown $D$, Coleman BG, Crum C et al. First International Consensus Report on Adnexal Masses: Management Recommendations. J Ultrasound Med 2017;36(5):849-63. [CrossRef] [PubMed]

11. Timmerman D, Van Calster B, Testa A, Savelli L, Fischerova $D$, Froyman $W$ et al. Predicting the risk of malignancy in adnexal masses based on the Simple Rules from the International Ovarian Tumor Analysis group. Am J Obstet Gynecol 2016;214(4):424-37. [CrossRef] [PubMed]

12. Giede KC, Kieser K, Dodge J, Rosen B. Who should operate on patients with ovarian cancer? An evidencebased review. Gynecol Oncol 2005;99:447-61. [CrossRef] [PubMed]

13. Vernooij F, Heintz AP, Coebergh JW, Massuger LF, Witteveen PO, van der Graaf Y. Specialized and highvolume care leads to better outcomes of ovarian cancer treatment in the Netherlands. Gynecol Oncol 2009;112:455-61. [CrossRef] [PubMed]

14. Naik R, Galaal K, Alagoda B, Katory M, Mercer-Jones $M$, Farrel R. Surgical training in gastrointestinal procedures within a UK gynaecological oncology subspecialty programme. BJOG 2010;117:26-31. [CrossRef] [PubMed]
15. Earle CC, Schrag D, Neville BA, Yabroff KR, Topor M, Fahey $A$, et al. Effect of surgeon specialty on processes of care and outcomes for ovarian cancer patients. J Natl Cancer Inst 2006;98:172-80. [CrossRef] [PubMed]

16. Topcu HO, Guzel AI, Ozer I, Kokanali MK, Gokturk U, Muftuoglu KH. Comparison of Neutrophil/Lymphocyte and Platelet/Lymphocyte Ratios for Predicting Malignant Potential of Suspicious Ovarian Masses in Gynecology Practice. Asian Pac J Cancer Prev 2014;15(15): 6239-41. [CrossRef] [PubMed]

17. Guthrie G], Charles KA, Roxburgh CS, Horgan PG, McMillan DC, Clarke SJ.The systemic inflammationbased neutrophil-lymphocyte ratio: experience in patients with cancer. Crit Rev Oncol Hematol 2013; 88(1):218-30. [CrossRef] [PubMed]

18. Bednarska K, Król E, Głowacka E, Romanowicz $H$, Szyło K, Klink M et al. Analysis of preoperative blood platelet parameters in terms of diversity of epithelial ovarian cancer. Medicine (Baltimore) 2018;97(12): 0180. [CrossRef] [PubMed]

19. Bakacak M, Serin S, Ercan Ö, Köstü B, Bostancı MS, Bakacak $Z$ et al. Utility of preoperative neutrophil-tolymphocyte and platelet-to-lymphocyte ratios to distinguish malignant from benign ovarian masses. J Turk Ger Gynecol Assoc 2016;17(1):21-5. [CrossRef] [PubMed]

20. Tian C, Song W, Tian X, Sun Y. Prognostic significance of platelet-to-lymphocyte ratio in patients with ovarian cancer: A meta-analysis. Eur J Clin Invest 2018; 48(5):12917. [CrossRef] [PubMed]

21. Templeton AJ, McNamara MG, Šeruga B, Vera Badillo FE, Aneja P, Ocaña A et al. Prognostic Role of Neutrophil-to-Lymphocyte Ratio in Solid Tumors: A Systematic Review and Meta-Analysis. JNCI 2014; 106(6):124. [CrossRef] [PubMed]

22. Petrie HT, Klassen LW, Kay HD. Inhibition of human cytotoxic $T$ lymphocyte activity in vitro by autologous peripheral blood granulocytes. J Immunol 1985; 134(1):230-4. [PubMed]

23. Gooden MJ, de Bock GH, Leffers $N$, Daemen $T$, Nijman $\mathrm{HW}$. The prognostic influence of tumor-infiltrating lymphocytes in cancer: a systematic review with meta-analysis. Br J Cancer 2011;105(1):93-103. [CrossRef] [PubMed]

24. Sylman JL, BoyceHB, Mitrugno A, Tormoen GW, Tomas IC, Wgner TH. Temporal Examination of Platelet Counts as a Predictor of Prognosis in Lung, Prostate, and Colon Cancer Patients. 2018;SciRep(8): 6564. [CrossRef] [PubMed]

25. Hanahan D, Weinberg RA. Hallmarks of cancer: the next generation. Cell 2011;144(5):646-74. [CrossRef] [PubMed]

26. Krleža $L$, Zadro $R$, Nakić $M$, Sucic M, Huzjak N, Jurucevic $M$ et al. Significance and usefulness of platelets indexes. Paediatria croatica 1999;43(2):7985.

27. Prodromidou A, Andreakos $P$, Kazakos C, Vlachos DE, Perrea D, Pergialiotis $V$. The diagnostic efficacy of platelet-to-lymphocyte ratio and neutrophil-tolymphocyte ratio in ovarian cancer. Inflamm Res 2017; 66(6):467-75. [CrossRef] [PubMed] 


\title{
MOGUĆNOST KORIŠĆENJA BIOHEMIJSKIH I HEMATOLOŠKIH PARAMETARA U PROCENI ADNEKSALNIH MASA
}

\author{
Aleksandra Petrić1,2, Radomir Živadinović1,2, Dejan Mitić1,2, Predrag Vukomanović1,2, \\ Jelena Milošević1,2, Aleksandar Živadinović ${ }^{2}$
}

${ }^{1}$ Univerzitet u Nišu, Medicinski fakultet, Niš, Srbija

${ }^{2}$ Univerzitetski klinički centar Niš, Klinika za ginekologiju i akušerstvo, Niš, Srbija

Kontakt: Aleksandra Petrić

Lole Ribara 3/17, 18000 Niš, Srbija

E-mail: sanja.petric@hotmail.com

Sadašnji dijagnostički pristup adneksalnim masama (anamneza, klinički pregled, transvaginalna sonografija, tumorski markeri) ne omogućava preciznu predikciju mogućeg maligniteta. Postoji mogućnost korišćenja hematoloških i biohemijskih parametara (broj trombocita, odnos neutrofila i limfocita, odnos trombocita i neutrofila, trombocitna širina, nivo C reaktivnog proteina) u predikciji ovarijalnog maligniteta.

Sprovedeno je retrospektivno istraživanje. Analiza pomenutih parametara kod bolesnica sa histopatološki verifikovanim benignim/malignim ovarijalnim tumorima.

Vrednosti CRP-a, ukupan broj granulocita i ukupan broj trombocita statistički su značajno veće kod bolesnica sa malignim promenama $(p<0,001, p=0,001$; odnosno $p=$ $0,023)$. Ukupan broj limfocita statistički je značajno manji kod bolesnica sa malignim promenama ( $p<0,001)$. Broj trombocita statistički je značajno veći kod bolesnica sa stadijumom III tumora $(p=0,011)$. Odnos Tr/LY statistički je značajno veći kod bolesnica sa stadijumom III tumora $(p=0,043)$. CRP je statistički značajno viši kod bolesnica III stadijuma tumora $(p<0,001)$. Broj limfocita statistički je značajno niži kod bolesnica III stadijuma tumora ( $p<0,001)$, a broj granulocita je statistički značajno veći kod bolesnica sa III stadijumom tumora $(p=0,001)$. Broj trombocita statistički je značajno veći kod bolesnica sa III stadijumom tumora $(p=0,001)$. MPV je statistički značajno manji kod bolesnica sa III stadijumom tumora $(p=0,031)$. Tr/Ly odnos statistički je značajno veći kod bolesnica na III stadijumom tumora $(p=0,044)$.

Ispitivani biohemijski i hematološki parametri su od ograničene vrednosti u diferencijaciji benignih od malignih ovarijalnih masa. Povišeni nivoi $C$ reaktivnog proteina, neutrofila $i$ trombocita ukazuju na, verovatno, malignu ovarijalnu masu. Ispitivani biohemijski parametri (visoki nivoi C reaktivnog proteina, nizak broj limfocita, viši broj granulocita, viši niovoi trombocita, povišeni odnos PLR-a, kao i niži nivoi MPV-a) mogu ukazati na uznapredovalu malignu bolest.

Acta Medica Medianae 2021;60(4):23-29

Ključne reči: karcinom jajnika, biohemijski, hematoloski parametri 